\title{
FUTURE SUSTAINABLE CONCENTRATING SOLAR POWER TECHNOLOGIES: A TECHNO-ECONOMICAL STUDY
}

\author{
A.M.K. El-Ghonemy \\ High Institute of Engineering and Textile Technology, Egypt \\ Email:amghonemy@yahoo.com
}

\begin{abstract}
The present study is a continuation of a previous work which titled by "Future sustainable Concentrating Solar Power (CSP) technologies: a review". Electricity production, HVAC and the production of safe drinking water constitute the major needs of developing countries. Consequently, the bulk of this new CSP capacity is expected to be seen in the MENA region, where it has abundant solar radiation, cheap land and high electricity demand. In this paper, the techno-economical study of using large scale CSP plant for electricity generation in Riyadh, KSA is investigated. Two cases are proposed for present and future applications. The first case (Case-1) is using parabolic trough (PT) solar field coupled with steam turbo-generator rated at capacity of 100MWe.The second case (Case-2) is using Solar tower/heliostats solar field coupled with gas turbo-generator at rated capacity of $100 \mathrm{MWe}$ system which is proposed for future application in desert areas. Then a parametric study was done to investigate the best economic TES hours for both cases. Finally the optimum condition of both cases is compared. The results showed that the estimated average annual electricity is 363,892 MWhe, $341,456 \mathrm{MWhe}$ for case- 1 and case- 2 respectively. Thus achieving a conversion efficiency of $18.67 \%, 14.87 \%$ for case- 1 and case-2 respectively. The financial results showed that: for case-1, $\mathrm{LCOE}_{\text {nominal }}$ is 16.97 , $21.8 \mathrm{Cent} / \mathrm{KWhe}$ at interest rate of $3 \%, 6 \%$ respectively. While for cas- 2 : the $\mathrm{LCOE}_{\text {nominal }}$ is 15.54 , $19.68 \mathrm{Cent} / \mathrm{KWhe}$ at interest rate of $3 \%, 6 \%$ respectively, which is still high comparing to the current electricity cost in KSA. Also, the minimum LCOE was obtained at $6 \mathrm{hrs}$ thermal energy storage for both cases. Finally, when carrying out feasibility studies for CSP plants, attention must be paid to fund at low interest rate, and local manufacturing for some items of the solar field. This can achieve a significant reduction in the LCOE.
\end{abstract}

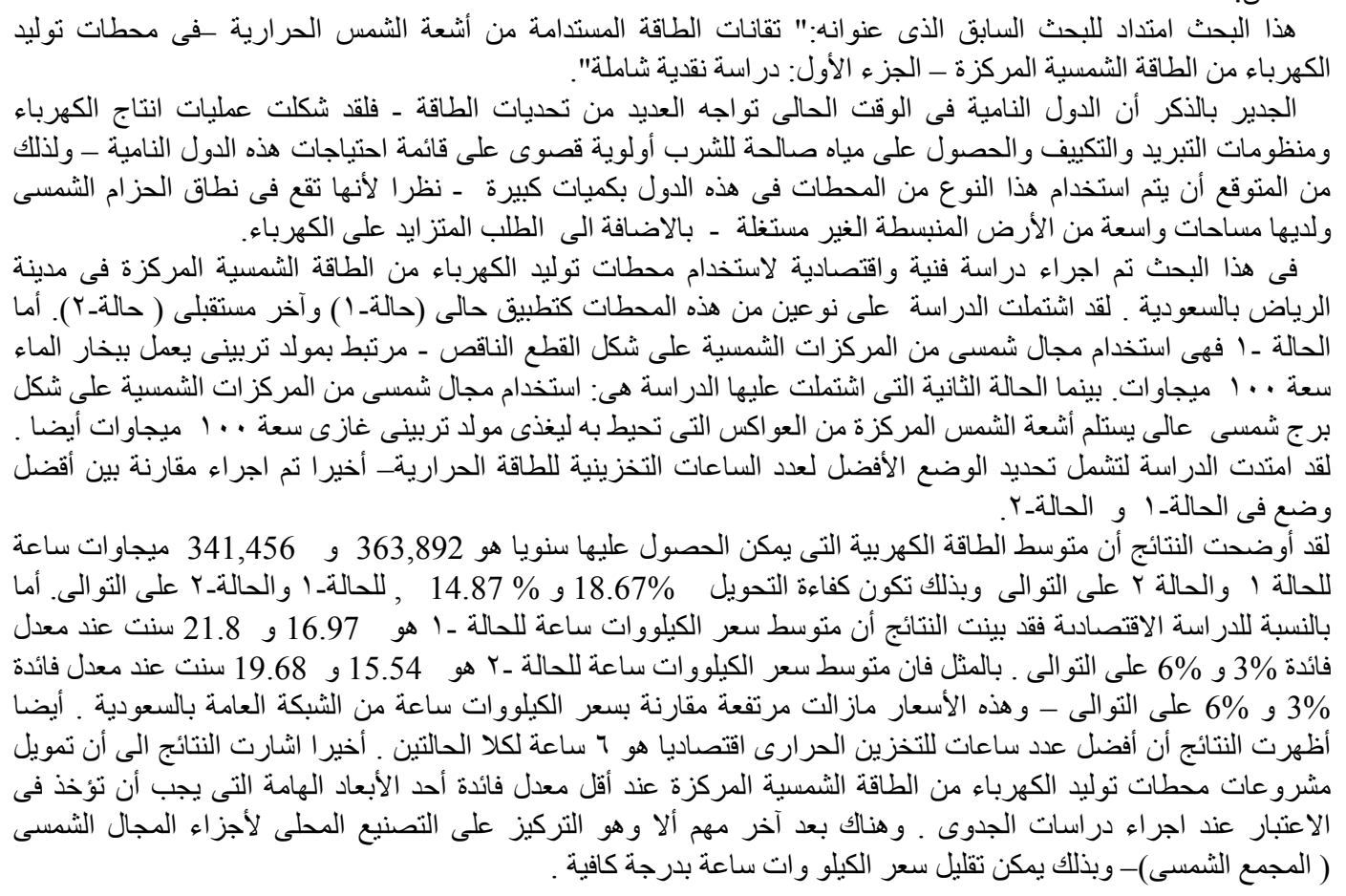

Keywords: Parabolic Trough Power Plant, Solar Tower Power Plant, Techno-Economical Study 


\section{Introduction}

All Middle East and North Africa (MENA) regions have an outstanding potential for solar energy. Growth of population and economy, increasing urbanization and industrialization, against the limited natural resources of potable water and energy in MENA are leading to serious deficits. All CSP technologies can be used for generating electricity and heat. The more focus is on CSP for Electricity production, HVAC and the production of safe drinking water because these constitute major needs of developing countries (MENA). Consequently, the bulk of this new CSP capacity is expected to be seen in the MENA region, where it has abundant solar radiation, cheap land and

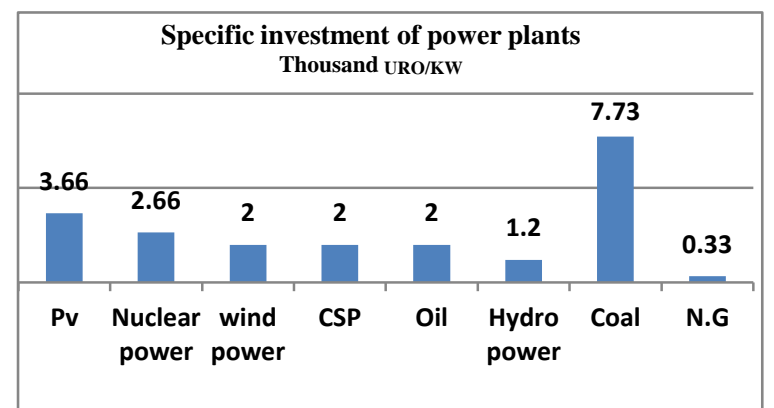

high electricity demand)[1].In addition, comparing to $\mathrm{PV}$, nuclear, wind plants, CSP plants has the lowest investment cost as seen in fig.(1) $[1,2]$.

Fig.(1). Comparing the specific Investment of power plants [2].

\subsection{Objectives}

In this paper, the techno-economical study of using large scale CSP for electricity generation in Riyadh, KSA is investigated, using the following two types of CSP systems as shown in figures $(2,3)$ :

- System-1: Parabolic trough(PT) solar field coupled with steam turbo-generator rated at $100 \mathrm{MW}_{\mathrm{e}}$

- System-2: solar tower (SoTo) solar field coupled with gas turbo-generator rated at $100 \mathrm{MW}_{\mathrm{e}}$, for future application in desert areas.

In general, all CSP technologies can be used for generating electricity and heat. The proposed two cases are the best two candidate for present (Case-1) and future applications (Case-2), due to the following reasons:-

-To assess the potential of large scale CSP for the major centers in MENA, parabolic dish systems can be excluded as they only operate in the kilowatt range.

- PT power plants represent about $88 \%$ of the worldwide installed CSP capacity and about $97.5 \%$ of all capacity which is currently under construction. So it will be studied with superheated steam power cycle with TES (Case-1), see fig.(2).
- In the high-temperature range up to $1000{ }^{\circ} \mathrm{C}$ and more, solar towers (Case-2) are the only available option to provide solar heat for gas turbines and combined cycle systems. This option is the best choice for desert areas. Noting that solar towers are still uncertain and still leaves open questions with respect to cost, reliability and scalability for mass production at large scale, see fig.(3). Then a parametric study is done to investigate the best TES hours for both cases. Finally the best conditions of both cases are compared.

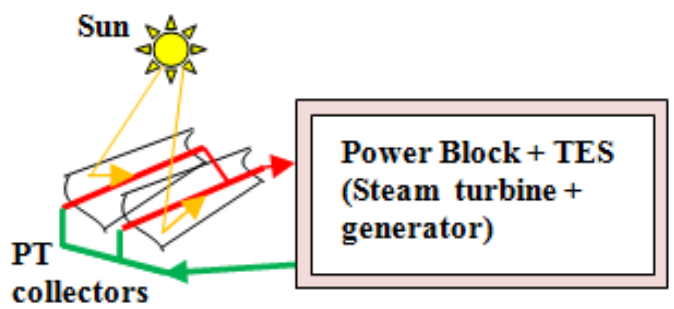

Fig. (2). Power trough + Steam turbine generation set proposed where water is available (Case-1)

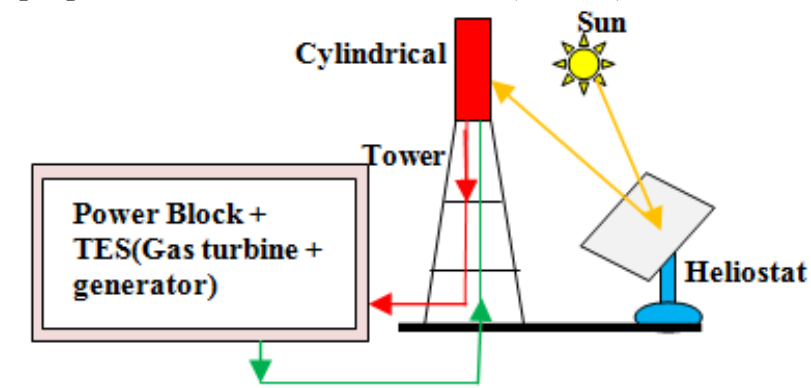

Fig.(3). Solar tower /heliostats+ Gas turbine generation set proposed for desert areas (Case-2)

\section{Solar Input Data for Sizing the System Components [5,6]}

For location outside USA, The weather file for Riyadh City (located in KSA) was downloaded from the internet (The weather data in EPW format for locations around the world at no cost from the Energy Plus weather data website [5]. The name of file is: SAM/SAU_Riyadh.epw. This file was places inside the weather library of SAM program to be opened and used during analysis.

\section{Current Performance of CSP Systems}

A comparison of the key parameters of the four types of CSP technologies is summarized in tables (1). These CSP technologies differ significantly from one to other, regarding technical, economic aspects, reliability, maturity and operational experience. 
Table(1). Performance indicators of Various CSP Technologies, $d=$ demonstrated, P=projected, solar efficiency= net power generated/incidence beam radiation, Capacity factor=solar operating hrs per year/8760 hrs per year.[15-24].

\begin{tabular}{|c|c|c|c|c|c|c|}
\hline Technology & $\begin{array}{c}\text { Capacity } \\
\text { range }(\mathrm{MW})\end{array}$ & $\begin{array}{l}\text { Concentrati } \\
\text { on }\end{array}$ & $\begin{array}{c}\text { Peak solar } \\
\text { efficiency }(\%)\end{array}$ & $\begin{array}{l}\text { Solar- } \\
\text { electric } \\
\text { efficiency } \\
(\%) \\
\end{array}$ & $\begin{array}{c}\text { Capacity } \\
\text { factor(solar) } \%\end{array}$ & $\begin{array}{l}\text { Land use } \\
\left(\mathrm{m}^{2} / \mathrm{MWh}\right)\end{array}$ \\
\hline Parabolic trough & $10-200$ & $70-80$ & 21 & $\begin{array}{l}10-15(\mathrm{~d}) \\
17-18(\mathrm{P})\end{array}$ & $\begin{array}{l}24(d) \\
25-90(P)\end{array}$ & $6-8$ \\
\hline Fresnel reflector & $10-200$ & $25-100$ & 20 & $9-11(\mathrm{P})$ & $25-90(\mathrm{P})$ & $4-6$ \\
\hline Solar tower//heliostat & $10-150$ & $300-1000$ & 20 & $\begin{array}{l}8-10(d) \\
15-25(P)\end{array}$ & $25-90(\mathrm{P})$ & $8-12$ \\
\hline Dish-Stirling & $0.01-0.4$ & $1000-3000$ & 29 & $\begin{array}{l}16-18(d) \\
18-23(P)\end{array}$ & $25(\mathrm{P})$ & $8-12$ \\
\hline
\end{tabular}

\section{Analysis[7-24]}

\subsection{The Key Items of Cost Analysis}

For any engineering project, Cost can be measured in two main categories, capital expenditure cost (CAPEX) and Operational expenditure cost(OPEX). Then the term named by Levelized cost of energy(LCOE) can be calculated.

\subsection{Capital Expenditure (CAPEX)[8-12]}

They include:

- mechanical equipment

- electrical equipment

- instrumentation\& Control

- civil works (transportation, construction)

- auxiliary systems

- site and infrastructure development costs

- project development cost (engineering)

- project management and consultancy services

Costs that are not included in the capital cost estimates are:

- Cost of land

- Interest charges during construction

- import taxes or duties

\subsection{Operational Expenditure (OPEX)}

The economic database comprises factors such as plant lifetime and interest rates. The various typical plant configurations are characterized by the operational data, comprising typical consumption and data for power, fuels and consumables as well as expenses for maintenance, personnel and insurance.

\subsection{Levelized Cost of Electricity (LCOE)}

LCOE is calculated using the following simple equation:

$$
\begin{aligned}
& \text { LCOE } \\
& =\frac{\text { Annualized capital costs }+ \text { annual O\&Mcosts }}{\text { Annual energy generated } X \text { availability }}
\end{aligned}
$$

The estimation of the levelized cost of electricity (LCOE) is based on the calculation of investment (or capital expenditures, CAPEX) and operational expenditures (OPEX). The OPEX include costs for fuel, personnel, maintenance, mirror\& absorber replacement, and insurance.

The levelized cost of electricity (LCOE) is the discounted lifetime cost divided by discounted lifetime generation. The formula used for calculating the LCOE of renewable energy technologies is:

$$
L C O E=\frac{\sum_{t=1}^{n} \frac{I_{t}+M_{t}+F_{t}}{(1+r)^{t}}}{\sum_{t=1}^{n} \frac{E_{t}}{(1+r)^{t}}}
$$

Where:

LCOE $=$ the average lifetime levelized cost of electricity generation;

$\mathrm{I}_{\mathrm{t}}=$ investment expenditures in the year $\mathrm{t}$;

$\mathrm{M}_{\mathrm{t}}=$ operations and maintenance expenditures in the year $\mathrm{t}$;

$\mathrm{F}_{\mathrm{t}}=$ fuel expenditures in the year $\mathrm{t}$;

$\mathrm{E}_{\mathrm{t}}=$ electricity generation in the year $\mathrm{t}$;

$\mathrm{r}=$ discount rate; and

$\mathrm{n}=$ life of the system.

Taking into account inflation, The LCOE is the price of electricity required for a project where revenues would equal costs making a return on the capital invested equal to the discount rate. An electricity price above this would yield a greater return on capital, while a price below it would be a lower return on capital, or a loss.

According to many researches on CSP technologies, the estimated LCOE ranged from $\$ 0.08 / \mathrm{KWh}_{\mathrm{e}}$ to $0.16 / \mathrm{KWh}_{\mathrm{e}}$ Approximately, a $95 \%$ probability that the LCOE will be less than $0.14 / \mathrm{KWh}_{\mathrm{e}}$ and a $5 \%$ probability that the LCOE will be greater than $0.14 / \mathrm{KWh}_{\mathrm{e}}$. There is approximately $0.9-0.2=0.7(70 \%)$ probability that the LCOE will be between $0.1 / \mathrm{KWh}_{\mathrm{e}}$ and $0.14 / \mathrm{KWh}_{\mathrm{e}}$. 


\subsection{The Key Financial Indicators [13-14]}

Always the first step is to determine the cash flows distributed over its economic lifetime (investment yearly revenues and costs). For making economic decisions, three indicators have to be calculated:

-payback period:

It is the amount of time in which the initial investment is recovered. The higher it is the worst is, the shorter it is the better is.

-Internal rate of return

Knowing the cash flows representing the costs and benefits of each case, the internal rate of return is defined as the interest rate at which present worth of costs is equal to present worth of benefits, this can be written as:

PW of costs- $\mathrm{PW}$ of benefits $=0$.

-Net present value (NPV)

It is used to determine the present value of future money receipts and disbursements. The higher NPV alternative should be selected. Also, if NPV= negative value) the project is costs. If not (NPV= positive)then the project is benefits. Else(NPV=0)which means the project is neutral.

\subsection{Technical Model [15-24]}

The total thermal energy output from a SF is obtained by multiplying the total incident solar energy by its optical and thermal efficiency. The total incident solar energy is calculated by multiplying the direct normal irradiation (DNI, $I_{b n}$ ) by the total SF aperture area $\left(A_{a p, t o t}\right)$ as given below:

$$
Q_{\text {Solar }}=I_{b n} A_{a p, t o t}
$$

Taking the effect of solar field different efficiencies such as optical efficiency $\left(\eta_{\text {optical }}\right)$, mirror cleanliness $\left(\eta_{\text {clean }}\right)$ and thermal efficiency $\left(\eta_{\text {thermal }}\right)$ then the output SF thermal energy is given by:

$$
Q_{S f, \text { out }}=Q_{\text {Solar }} \cdot \eta_{\text {optical }} \cdot \eta_{\text {clean }} \cdot \eta_{\text {thermal }}
$$

Where $Q_{S f, \text { out }}$ is calculated with reference to the desired power block output $\left(\dot{W}_{p b}\right)$ and the solar multiple $\left(\mathrm{M}_{\mathrm{s}}\right)$ :

$$
Q_{S f, \text { out }}=\frac{\dot{W}_{p b} \cdot M_{s}}{\eta_{c y c l e}}
$$

At the end the monthly net electricity generated from incidence solar power is estimated.

\subsection{Financial Model [7-14]}

Financial models calculate a project's cash flow over a specified period. The cash flow captures the value of electricity generated by the system and incentives, and the cost of installation, operation and maintenance, taxes, and debt.

For large scale CSP projects (> $500 \mathrm{~kW}$ ), electricity has to be sold at a price negotiated through a power purchase agreement (PPA) (at a given minimum attractive rate of return $\left(\operatorname{IRR}_{\min }\right)$ ). Levelized cost of energy (LCOE) is calculated, which represents the cost of installing and operating the system, including both of CAPEX and OPEX. Also, the net present value of the after tax cash flow is calculated. Finally a payback period representing the number of years required for the cumulative after tax cash flow to cover the initial equity investment in the project.

Now, the following equations are given:

1-knowing of analysis Period, Inflation Rate, Real Discount Rate, the Nominal Discount Rate is:

Nominal Discount Rate $=(1+$ Real Discount Rate $)$ $\times(1+$ Inflation Rate $)-1$

2-knowing the $1^{\text {st }}$ year electricity output (obtained from the technical model), and assuming degradation factor of $1 \%$, the other years electricity generation can be estimated.

$$
\begin{gathered}
K W h_{e} @ \text { yearn }= \\
\left(K W h_{e}\right)_{\text {year } 1}(1-\text { Degradation } \%)^{n-1},
\end{gathered}
$$

where $\mathrm{n}=2: \mathrm{n}$, and $\left(K W h_{e}\right)_{\text {year } 1}$ is the electricity generated during the $1^{\text {st }}$ year as estimated from the technical model.

3-yearly Electricity sales price:

$$
\begin{aligned}
\left(\$ / K W h_{e}\right)_{\text {yearn }}= & \left(\$ / K W h_{h}\right)_{\text {year } 1} \cdot(1 \\
& + \text { inflationrate })^{n}
\end{aligned}
$$

Where $\left(\$ / K W h_{e}\right)_{\text {year } 1}$ is the first year price which obtained from the min. attractive IRR

4- Yearly Cash inflows (revenues):

The yearly income cash flows can be estimated by

$\$ /$ year $n=+K W h_{e} @$ yearn..$\left(\$ / K W h_{e}\right)_{\text {yearn }}$

5-yearly Cash outflows(Costs):

a- OPEX expenses:

$$
\begin{aligned}
& (\text { OPEX }, \$ / \text { year })_{n} \\
& =(\text { OPEX }, \$ / \text { year })_{\text {year } 1} \cdot(1 \\
& + \text { inflationrate } \\
& + \text { Escalationrate })^{n-1}
\end{aligned}
$$

\section{$b$ - Insurance costs}

(Insurance, $\$ /$ year $)_{n}$ $=($ totalinvestmentcosts,$\$)($ insyrancerate $)(1$ + inflationrate $)^{n-1}$ 
c- Financing costs:

Considering the total investment cost as a present value, so the equivalent annual equity can be obtained

$$
\begin{aligned}
& \text { (Principleamount, \$) yearn } \\
& =(\text { totalinvestmentcost }, \$)\left[\frac{i(i+1)^{n}}{(i+1)^{n}-1}\right]
\end{aligned}
$$

\section{d-Depreciation costs}

Depreciation of capital equipment is an important component of many after-tax economic analyses. Modified accelerated cost recovery system(MACRS) depreciation is selected to be used here. For the present application, 5-Year recovery period is recommended. MACRS depreciation schedule, applies to the first five years of the project life as follows: $20 \%, 32 \%, 19.2 \%, 11.52 \%, 11.52 \%$, and $5.76 \%$.

Hence the total yearly expenses can be obtained by summation of items a, b, c and d.

6- Calculating the yearly net Cash flows: by subtracting item 5 from item 4

7-Cumulative discounted cash flows: This can be obtained using Excel sheet,

8-Calculation of financial indicators: LCOE, NPV: also, using formulas in Excel sheet.

\section{Current Costs of CSP Plants [19-24]}

\section{I- Capital investment cost (CAPEX)}

Unlike power plants fired by fossil fuels, the LCOE of CSP plants are dominated by the initial investment cost, which accounts for approximately four-fifths of the total cost. The rest is the cost for operation and maintenance of the plant and for plant insurance.

The current CSP market is dominated by the parabolic trough technology. More than $80 \%$ of the CSP power plants in operation or under construction are based on this technology. As a consequence, most of the available cost information refers to parabolic trough systems.

The current investment cost for parabolic trough and solar tower//heliostats plants without storage are between $\$ 4500 / \mathrm{kW}$ and $\$ 7150 / \mathrm{kW}$. CSP plants with thermal energy storage tend to be significantly more expensive, but allow higher capacity factors, the shifting of generation to when the sun does not shine and/or the ability to maximize generation at peak demand times.

The cost of PT and ST plants with thermal energy storage is generally between $\$ 5000$ and $\$ 10500 / \mathrm{kW}$.

Although CSP plants with thermal energy storage have higher investment costs $(\$ / \mathrm{kW})$ due to the storage system and the larger solar field, the greater electricity generation will result in a lower electricity cost. Therefore, energy storage should be considered, as it can reduce the cost of electricity generated by the CSP plant and increase electricity production (capacity factors).

\section{II-Operation and maintenance costs (OPEX)}

The operating costs of CSP plants are low compared to fossil fuel-fired power plants. The O\&M costs data of recent CSP plants are not publically available. However O\&M costs of the Californian SEGS plants was estimated to be $\$ 0.04 / \mathrm{kWh}$.

The replacement of receivers and mirrors, due to glass breakage, are a significant component of the O\&M costs. The cost of mirror washing, including water costs, is also significant. Plant insurance is also an important expense. Thus the annual OPEX cost was estimated to be $0.5 \%$ to $1 \%$ of the initial capital cost.

The O\&M maintenance costs of modern CSP plants are lower than the Californian SEGS plants, as technology improvements have reduced the requirement to replace mirrors and receivers. Automation has reduced the cost of other O\&M procedures by $30 \%$. As a result of improved O\&M procedures (both cost and plant performance), total O\&M costs of CSP plants in the longer run are likely to be below $\$ 0.025 / \mathrm{kWh}$.

It is currently estimated that a parabolic trough system in the United States would have O\&M costs of around $\$ 0.015 / \mathrm{kWh}$, comprised of $\$ 70 / \mathrm{kW} /$ year fixed and around $\$ 0.003 / \mathrm{kWh}$ in variable costs. However, this excludes insurance, so care should be taken in interpreting this value. Given that insurance alone typically adds $0.5 \%$ to $1 \%$, which is equivalent to a figure of $\$ 0.02 / \mathrm{kWh}$ to $\$ 0.03 / \mathrm{kWh}$.

The O\&M costs of the two proposed PT and ST projects in South Africa were estimated to be \$ 0.029 - \$0.036/kWh(including insurance).

For the proposed $100 \mathrm{MW}$ PT plant with nine hours of thermal energy storage, fixed O\&M costs account for $92 \%$ of the total O\&M costs of $\$ 14.6$ million per year. The individual values of fixed O\&M are 4.7, 3.8, 3.5, 2.5 (\$ million/KWh) for solar field $\&$ storage system, insurance, staff costs and the power block respectively. The variable O\&M costs (miscellaneous consumables) which is at $\$ 0.7$ million, account for more than half of the total variable costs which is $\$ 1.2$ million per year.

In developed countries, personnel costs will be lower. For instance, personnel costs for a $100 \mathrm{MW}$ parabolic trough plant in the United States would account for $45 \%$ of the total O\&M costs, while it is $23 \%$ of the total costs in the proposed South African plant. 


\section{Assumptions [10]}

All data required for simulating the studied two cases are listed in tables (2.a, b and c). This data are: Geometrical parameters, costing data, and financing data.

Table (2.a). Input Data used for case-1.

\begin{tabular}{|c|c|}
\hline Parameter & Case-1 \\
\hline Average focal length & $5 \mathrm{~m}$ \\
\hline Distance between adjacent SCA's in a row & $1 \mathrm{~m}$ \\
\hline Distance between SCA rows & $15 \mathrm{~m}$ \\
\hline Width of SCA aperture(mirror width) & $5 \mathrm{~m}$ \\
\hline Solar field availability & 0.96 \\
\hline Number of SCA's in a row & 8 \\
\hline Length of single SCA & 100 \\
\hline Twisting and tracking error & 0.99 \\
\hline Mirror geometric accuracy & 0.98 \\
\hline Mirror reflectivity & 0.935 \\
\hline Mirror cleanliness & 0.951 \\
\hline HTF outlet temp & $400 \mathrm{C}$ \\
\hline \multicolumn{2}{|l|}{ Power plant } \\
\hline Conversion efficiency & $37.7 \%$ \\
\hline Boiler operating pressure & 100 bar \\
\hline Steam Inlet temp & $400 \mathrm{C}$ \\
\hline \multicolumn{2}{|l|}{ Costs } \\
\hline \multicolumn{2}{|l|}{ Direct capital costs } \\
\hline Site improvement & $30 \$ / \mathrm{m}^{2}$ \\
\hline Solar field & $270 \$ / \mathrm{m}^{2}$ \\
\hline HTF system & 80 \\
\hline Storage & $80 \$ / \mathrm{kWht}$ \\
\hline Power plant & $830 \$ / \mathrm{kWe}$ \\
\hline Balance of plant & $110 \$ / \mathrm{kWe}$ \\
\hline contingency & $7 \%$ \\
\hline Indirect Capex & $11 \%$ of $\mathrm{DC}$ \\
\hline \multicolumn{2}{|l|}{ OPEX } \\
\hline Fixed cost by capacity & $65 \$ / \mathrm{kWe}$ \\
\hline Variable cost by production & $4 \$ / \mathrm{kWhe}$ \\
\hline \multicolumn{2}{|l|}{ Financing } \\
\hline Debt fraction & $100 \%$ \\
\hline Loan compound interest rate/year & $6 \%$ \\
\hline Loan period & $25 \mathrm{yrs}$ \\
\hline
\end{tabular}

Table (2.b). Input Data used for case-2

\begin{tabular}{lcl}
\hline Parameter & Value & Units \\
\hline & & \\
Mirror reflectance and soiling & 0.9 & \\
Heliostat availability & 0.99 & \\
Image error & 0.002 & Rad. \\
heliostat L & 12.2 & $\mathrm{~m}$ \\
heliostat H & 12.2 & $\mathrm{~m}$ \\
Ratio of reflective area to profile & 0.97 & \\
Receiver Coating emmittance & 0.88 & \\
Receiver Area & 605.3 & $\mathrm{~m}^{2}$ \\
& 71 & \\
Receiver type & exter & \\
Power cycle & nal & \\
Power cycle Conversion efficiency & & \\
HTF inlet T & $45 \%$ & \\
Air pressure & 1000 & $\mathrm{C}$ \\
TES & 15 & $\mathrm{bar}$ \\
Full load hrs of TES & & \\
\hline
\end{tabular}

Table (2.c). Solar tower/heliostats power plant costing data, case-2

$\begin{array}{ll}\text { Site improvement } & 20 \$ / \mathrm{m}^{2} \\ \text { Heliostat field } & 201 \$ / \mathrm{m}^{2} \\ \text { Balance of the plant } & 345 \$ / \mathrm{kWe} \\ \text { Power block } & 795 \$ / \mathrm{kWe} \\ \text { storage } & 30 \$ / \mathrm{kWht} \\ \text { total Receiver cost } & \$ 38,693,298.31 \\ \text { Contingency } & 10 \% \\ \text { Contingency } & \$ 45,237,093.51 \\ \text { total direct cost } & \$ 497,608,028.66 \\ \text { Indirect costs } & \\ \text { land area,(acres) } & 1,293 \\ \text { Total land cost } & \$ 17,416,281.00 \\ \text { Sales tax applied to } 80 \% \text { of direct cost } & \$ 1,990,432.11 \\ \text { Total indirect cost } & \$ 94,047,917.42 \\ \text { Total installed cost } & \$ 591,655,946.08 \\ \text { Total installed cost/net capacity } & \$ 5,913.60 \\ \text { OPEX (O\&M costs) } & \\ \text { fixed by capacity, } \$ \mathrm{KWh} \text {-year } & 80 \\ \text { variable by generation } \$ / \mathrm{MWh} & 3\end{array}$



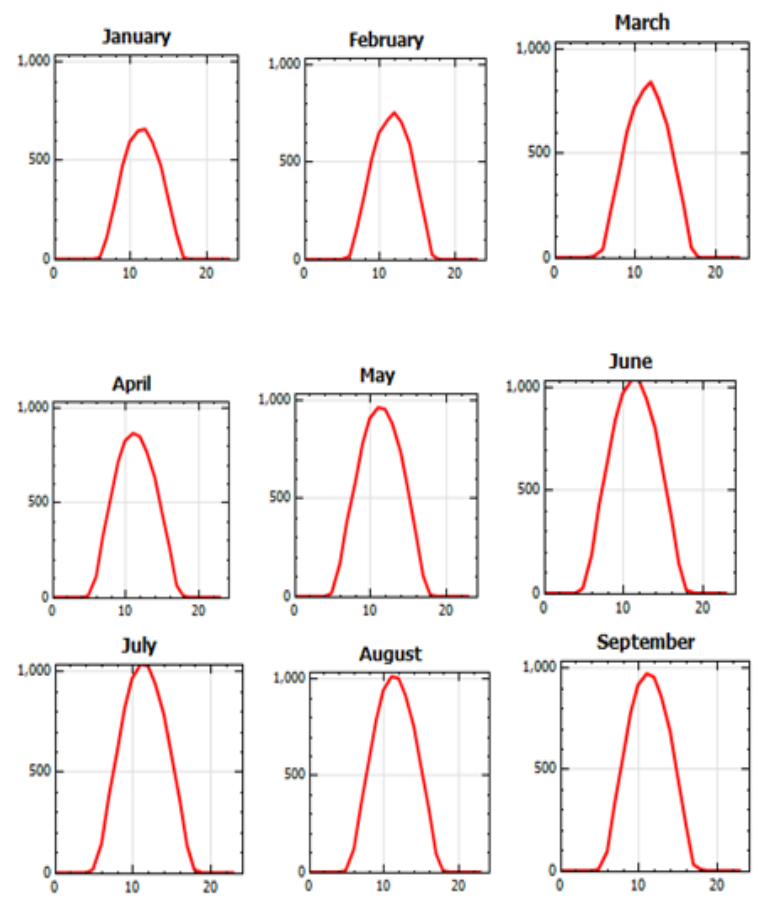

October
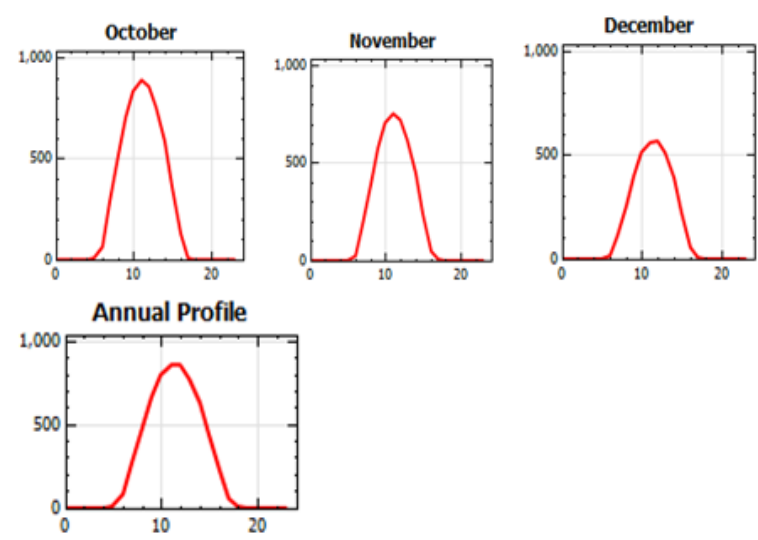

Fig.(4).Hourly solar DNI for Riyadh city location.

\section{Solution Technique [8-12]}

System Advisor model (SAM, version:30-11-2012) is based on an hourly simulation program which is used hereto simulate CSP plants performance, cost, and finance models to calculate energy output, energy costs, and cash flows. The inputs listed in Tables (3) were applied for the examined two cases.

\section{Results and Discussion}

The key questions to be answered here is how much of incoming beam solar radiation reaches the absorber (optical and geometric losses), how much the thermal energy is converted into electrical energy in the power block (thermal efficiency of turbogenerator set). Also by the same way, at what cost of KWh (LCOE). These questions can be answered throughout the following results.

\subsection{Solar Intensity at the Plant Location (Riyadh, KSA)}

The hourly solar DNI values are obtained and plotted in fig.(4). From the raw data, a considerable amount of annual average DNI was noticed (2266.3 $\mathrm{kWh} / \mathrm{m}^{2}$ ). Also, higher annual average sunshine hours was observed ( $>10 \mathrm{hrs} /$ day). Then based on DNI, and considering the optical and thermal losses, the plant monthly outputs is optained and plotted for both cases.

\subsection{Results of Case-1}

\section{a-Plant monthly net electric output}

The monthly plant net output from case- 1 is plotted in fig.(5). It is clear that the min value was recorded in Dec month, while the highest one is at june month.

How much of solar energy is converted into electric power is related to the optical and thermal efficiencies. The monthly net electric power is shown in figure (5). As shown in figs.(5:8), the results of case- 1 are discussed here:

The average annual DNI (Riyadh city, KSA) $=2266.3 \mathrm{Kwh} / \mathrm{m}^{2} \times$ the total aperture area of solar field is $860,000 \mathrm{~m}^{2}$ (215 loops, each loop has aperture area of $4000 \mathrm{~m}^{2}$, each loop contains 8 collectors of $500 \mathrm{~m}^{2}$ aperture area (width $\mathrm{x}$ length $\left.=5 \times 100 \mathrm{~m}\right)=$ $1,949,018 \mathrm{MWt}$ of annual thermal output. Due to optical and geometric losses in SF, amount of $1,083,428 \mathrm{MWt}$ is received by HCE. By the same way, due to thermal losses from HCE, a mount of $1,057,786 \mathrm{MWe}$ is received by power block (turbinegenerator set). Finally, considering the efficiency of turbo-generator set, a net value of 363,892 MWe is received as electricity that can be supplied to the grid.

A graph of the overall efficiency is shown in figure (8), which indicates the conversion factors from solar energy to final electrical energy 


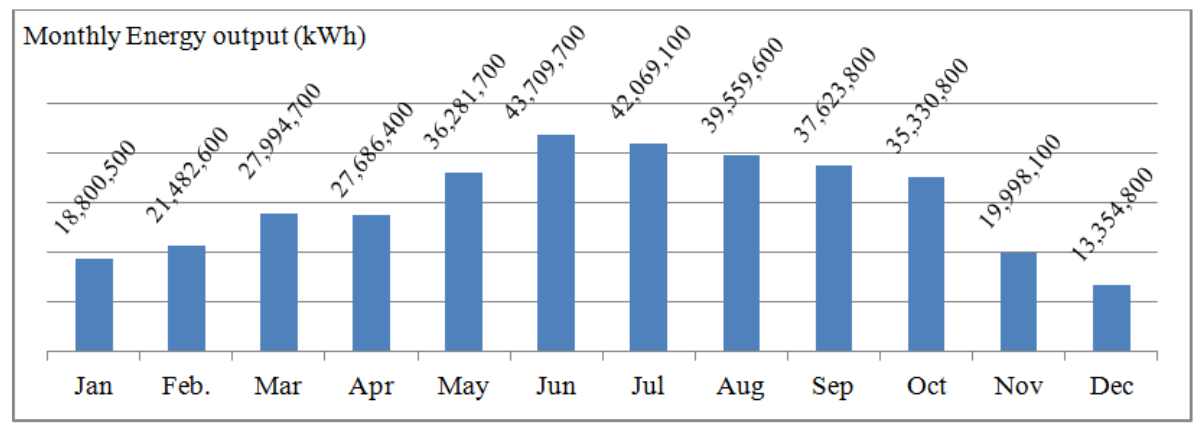

Fig.(5). Monthly energy output (Case-1).

\begin{tabular}{|c|c|c|c|c|}
\hline \multicolumn{5}{|l|}{$1,949,040$} \\
\hline & $1,083,430$ & $1,057,790$ & & \\
\hline & & & 389,573 & $363,892,000$ \\
\hline $\begin{array}{c}\text { Total Incident Sola } \\
\text { Radiation (kWh) } \\
\text { annual }\end{array}$ & $\begin{array}{l}\text { I Thermal Energy From } \\
\text { Solar Field (kWh) } \\
\text { annual }\end{array}$ & $\begin{array}{c}\text { n Thermal Energy to } \\
\text { Power Block (kWh) } \\
\text { annual }\end{array}$ & $\begin{array}{l}\text { Gross Electric Output } \\
(\mathrm{kWh}) \text { annual }\end{array}$ & $\begin{array}{l}\text { Net Electric Output } \\
(\mathrm{kWh}) \text { annual }\end{array}$ \\
\hline
\end{tabular}

Fig.(6). Annual energy flow, $\mathrm{kWh}$ (case-1) .

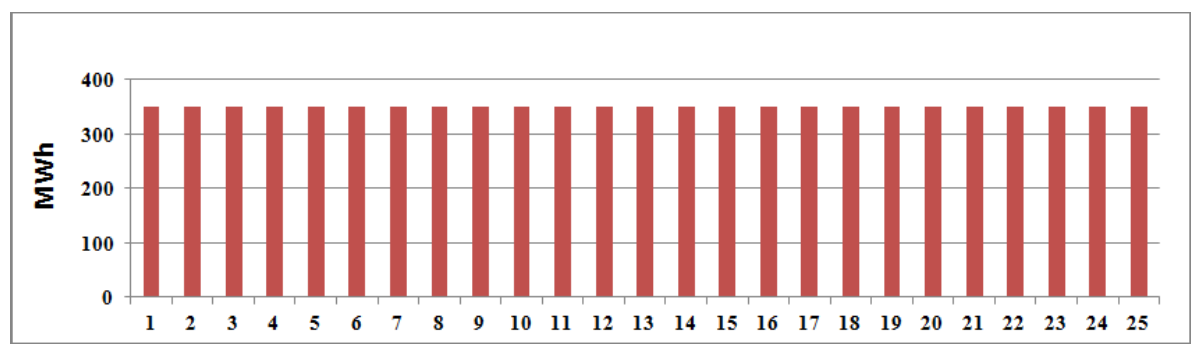

Fig.(7). Annual output of electricity through the complete lifetime(case-1) (neglecting the annually degradation).

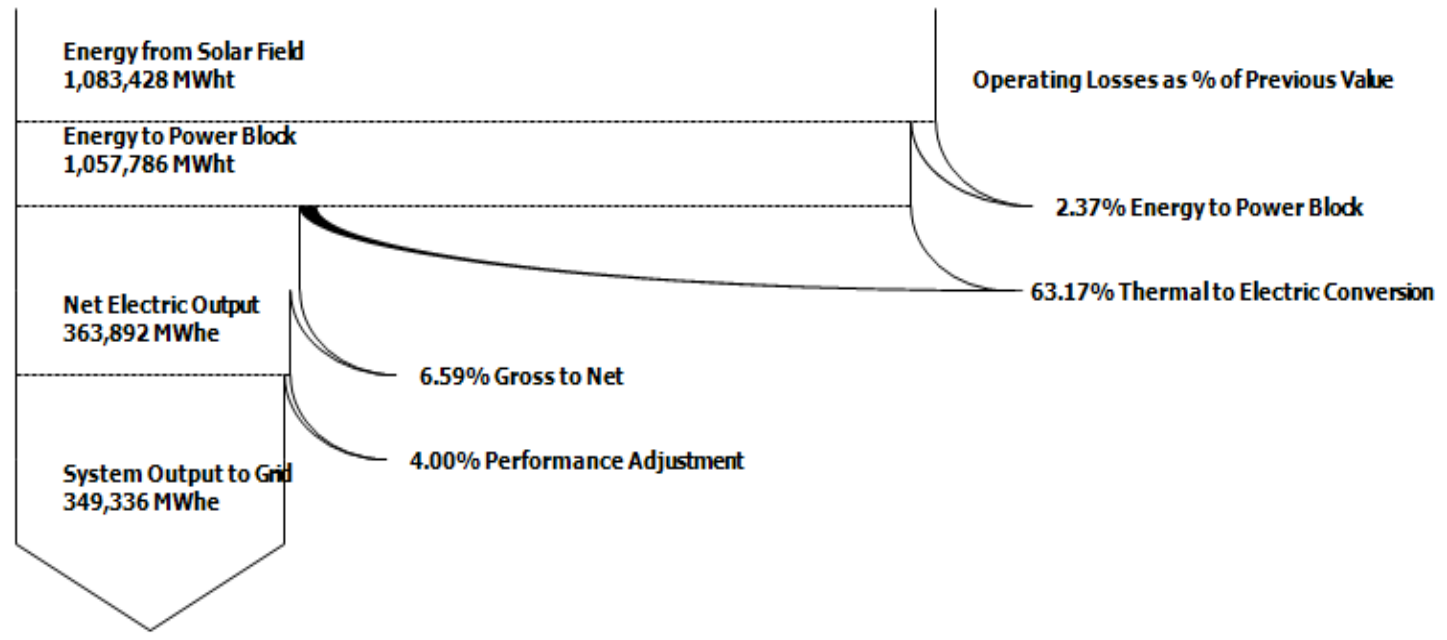

Fig.(8). Annual energy distrubution for case-1. 


\section{b-Cost analysis}

The cost breakdown is shown in fig.(9). The key items are ranked as: SF,TES, Power plant, HTF. This ranking is useful in future development and cost reduction potentials of CSP plants.

\section{c-Financial results and economical decision}

Based on calculating the key financial indicators (NPV, LCOE, Payback period), the economic decision can be taken. Here at a given minimum attractive rate of return $\left(\mathrm{IRR}_{\min }=15 \%\right)$. the $\mathrm{LCOE}$, PPA, and the NPV of the after tax cash flow is calculated.

The results of both financial scenarios are listed in table (4) according to CFD shown in fig.(10).

\section{d-The best condition of TES}

A thermal energy storage system (TES) stores heat from the solar field in a liquid medium. Heat from the storage system can drive the power block turbine during periods of low or no sunlight. It is expressed in number of hours of thermal energy delivered at the power block. The physical capacity is the number of hours of storage multiplied by the power cycle design thermal input.
Figure (11) shows the relationship between LCOE and the solar multiple for each storage capacity, it is clear that the best TES of 6 storage hours(at solar multiple of two)was obtained at the Lowest value of LCOE. Also, Lower values of LCOE can be achieved without storage and smaller solar multiples, but a higher capacity factor is needed. The 3 hours are also suitable for solar multiple and with similar LCOE; this is the matter of the capacity factor needed. As a conclusion, the solar multiple two with storage of 6 hours is technically and economically the best choice.

\section{e- Effect of the plant location (DNI)}

Generally, the first step in studying CSP projects is to consider the DNI of the proposed site. There is a certain minimum level of DNI that makes the CSP project feasible. Different DNI of different cities were selected and compared based on NPV indicator, as shown in fig.(12). From this figure, to make the project feasible, the NPV should be positive and has higher values. Thus, the min. DNI is selected to be about $2000 \mathrm{KWh} / \mathrm{m}^{2}$.

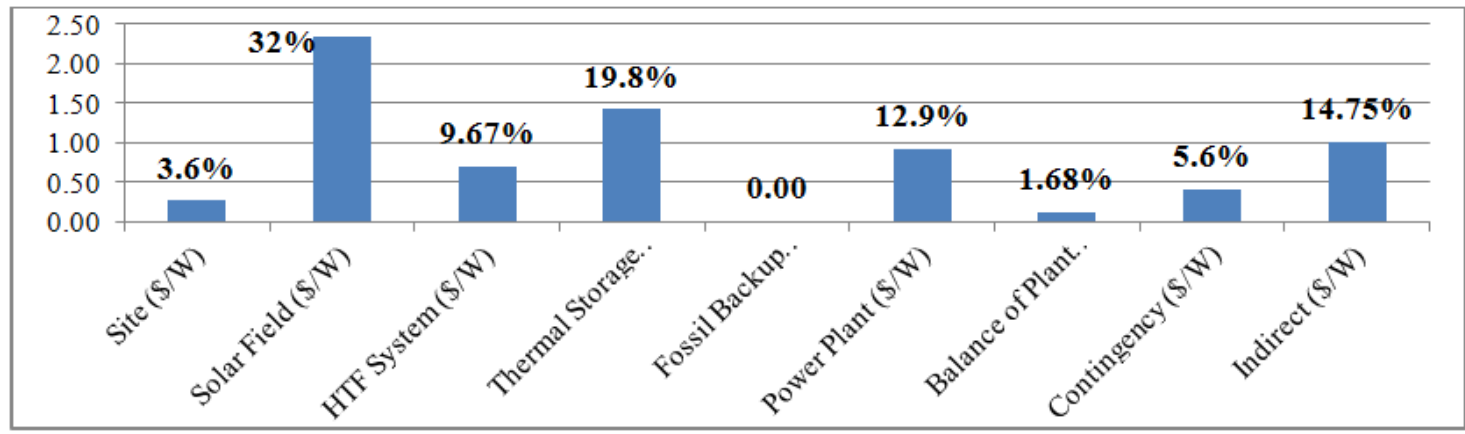

Fig.(9). Share of the plant componenets in the total capital cost(case-1).

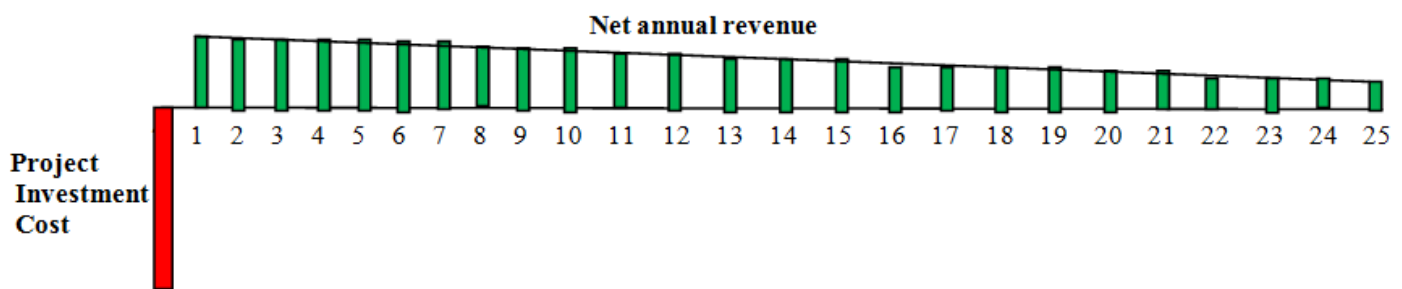

Fig.(10).Simplified Cash flow diagram .

Table (3). The key financial indicators for Case-1

\begin{tabular}{ccccc}
\hline & NPV & $\begin{array}{c}\text { LCOE } \\
\text { Nominal, } \mathbf{c} / \mathbf{k W h e}\end{array}$ & $\begin{array}{c}\text { LCOE } \\
\text { Real, } \mathbf{c} / \mathbf{k W h e}\end{array}$ & $\begin{array}{c}\text { PPA } \\
\text { price, } \mathbf{c} / \mathbf{k W h e}\end{array}$ \\
\hline Financing Senario-1(i=3\%) & $\begin{array}{c}225,840,080 \\
\text { (Revenue) }\end{array}$ & 16.97 & 13.41 & 13.17 \\
Financing Senario-2(i=6\%) & $\begin{array}{c}237,612,912 \\
\text { (Revenue) }\end{array}$ & 21.80 & 17.24 & 16.93 \\
\hline
\end{tabular}




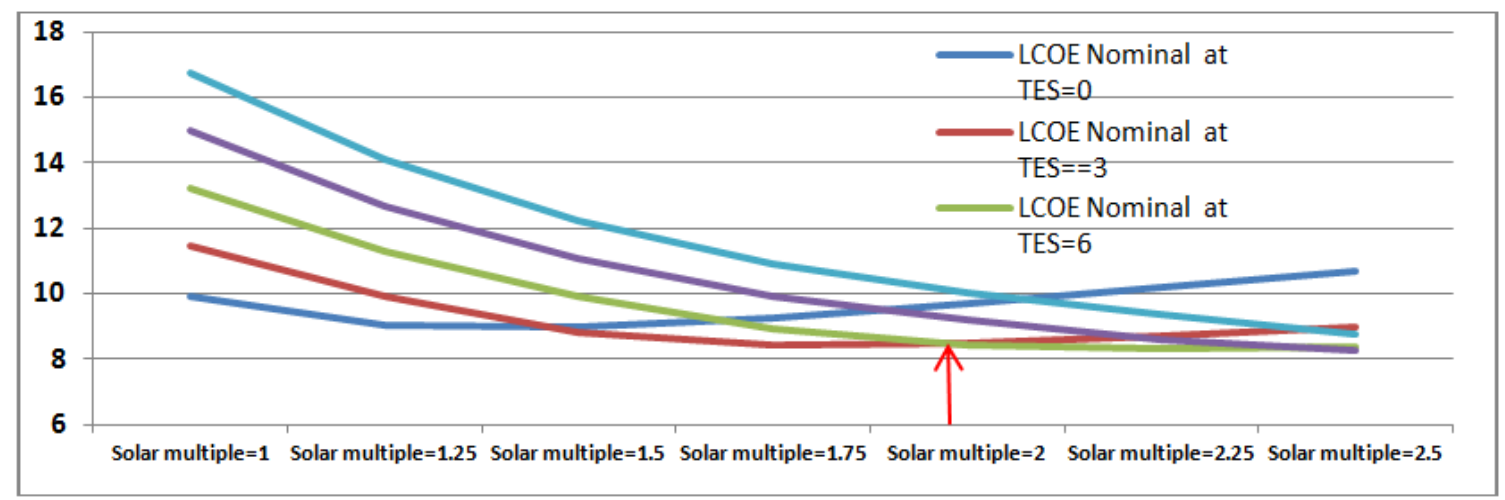

Fig.(11).Variation of LCOE versus SM at different storage capacities(case-1).

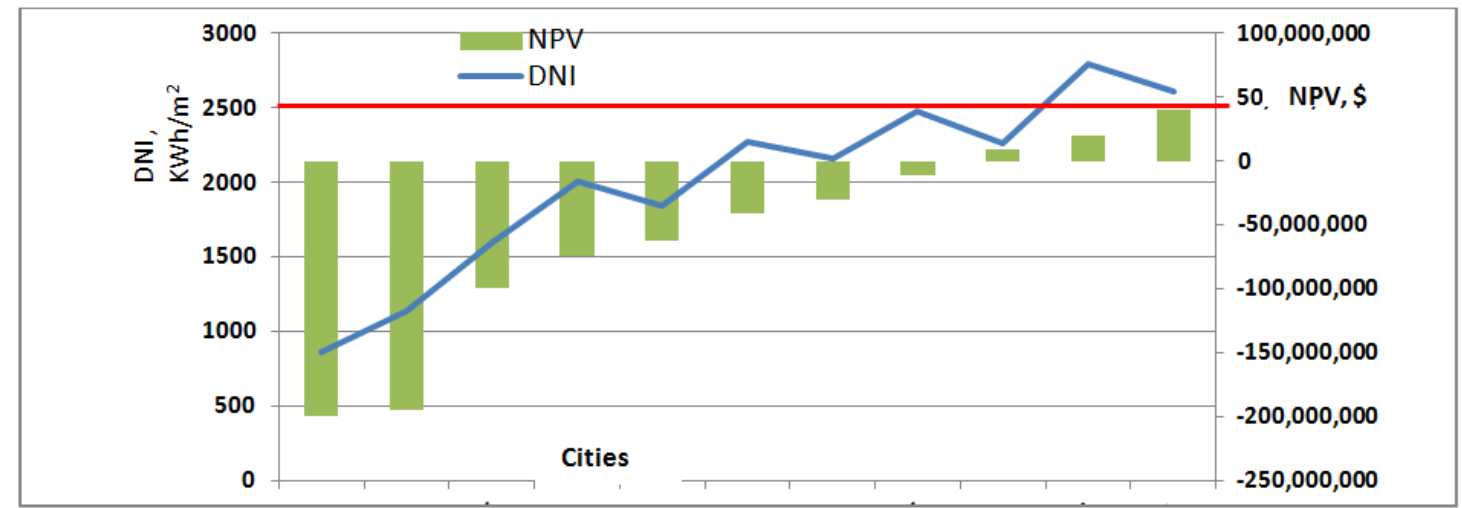

Fig.(12).Effect of DNI of varies cities on Financial decision, NPV

\subsection{Results of Case-2}

The same way of discussion used in case- 1 is used here for case-2.

a- The average annual DNI (Riyadh city, KSA) $=2266.3 \mathrm{kWh} / \mathrm{m}^{2}$, the total solar field (heliostat) area is $1,012,933.6 \mathrm{~m}^{2}$ (7016 heliostat, each one has area of $\left.144.375 \mathrm{~m}^{2}\right)=2,295,611 \mathrm{MWht}$ of annual thermal as input received by solar field. Due to optical and geometric losses in SF, a value of 888,096 MWht is the output from SF which is received by HCE. By the same way, due to thermal losses from HCE, a value of 882,060 MWht is received by power block (turbine-generator set). Finally, considering the efficiency of turbo-generator set, a net value of 341,456 MWhe is received as net electric output, see fig.(13).

A graph of the overall efficiency is shown in figure (14), which indicates the conversion factors from solar energy to electrical energy.

\section{b-Cost analysis}

The cost breakdown is shown in fig.(15). The key items are ranked as: SF,TES, Power plant, HTF. This ranking has to be considered in future development and cost reduction of CSP plants. Als, the LCOE for both financing scnario is listed in table(5).
Tables of compound interest were used for calculating the key financial indicators (NPV, Payback period). Thus economical decision can be taken. The results of both financial scenarios are listed in table (5). From table, scenario- 1 is the best choice.

\section{c-The best condition of TES}

Figure(16)shows the relationship between LCOE and the solar multiple for each storage capacity, it is clear that the best LCOE of energy for 6 storage hours is at a solar multiple of two lower values can be achieved without storage and smaller solar multiples, but a higher capacity factor is needed. The 3 hours are also suitable for solar multiple and with similar LCOE; this is the matter of the capacity factor needed. As a conclusion, the solar multiple two with storage of 6 hours is technically and economically the best choice.

\subsection{Comparison between the Studied Two Cases}

The key performance parameters for both cases are listed and compared in table(4). The main difference is that case-2 requires water for periodical cleaning of mirrors $\left(0.6 \mathrm{Litre} / \mathrm{m}^{2}\right.$ of aperture $\times 63$ washing times per year). On the other hand, case-1, consume more water for mirror washing + boilers blowdown+ the need for condenser cooling water. This is why case- 2 is the best candidates for use in desert area in future. 
In addition, from table(4) it is clear that funding at low interest rate $(3 \%)$ has a consederable effect on the LCOE for both cases. This parameter has to be considered when making a feasability study for CSP projects.

Table (4).Comparison between the studied two cases at 3\% and 6\% interest rates.

\begin{tabular}{lllll}
\hline & Case-1 @ $\mathbf{6 \%}$ & Case-1 @ 3\% & Case-2 @6\% & Case-2 @3\% \\
\hline Annual Energy, kWhe & $349,180,832$ & $349,180,832$ & $320,968,864$ & $320,968,864$ \\
PPA price, $\phi / \mathrm{k}$ Whe & 16.93 & 13.17 & 15.07 & 11.90 \\
LCOE Nominal, $\phi / \mathrm{kWhe}$ & 21.80 & 16.97 & 19.68 & 15.54 \\
LCOE Real, $\phi / \mathrm{kWhe}$ & 17.24 & 13.41 & 15.88 & 12.54 \\
Net present value $(\$)$ & $237,612,912$ & $225,840,080$ & $181,633,888$ & $173,168,656$ \\
Capacity factor, $\%$ & $39.9 \%$ & $39.9 \%$ & $36.6 \%$ & $36.6 \%$ \\
Annual Water Usage, $\mathrm{m}^{3}$ & $1,325,474$ & $1,325,474$ & 38,288 & 38,288 \\
Total Land Area, acres & 892.53 & 892.53 & 1292.92 & 1292.92 \\
\hline
\end{tabular}

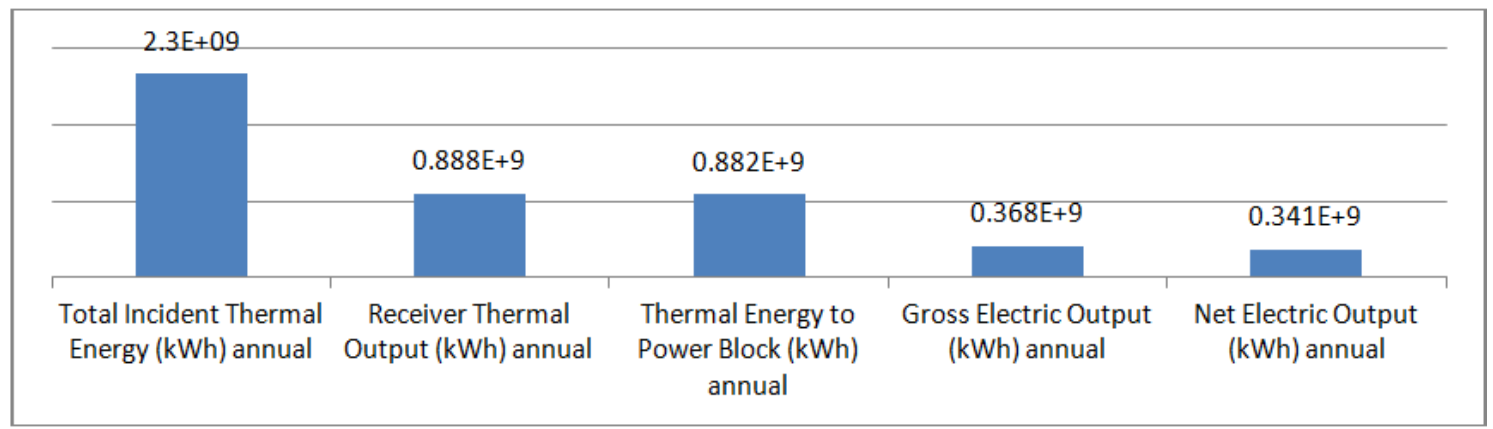

Fig.(13). Annual energy flow, $k W h$ (case-2).

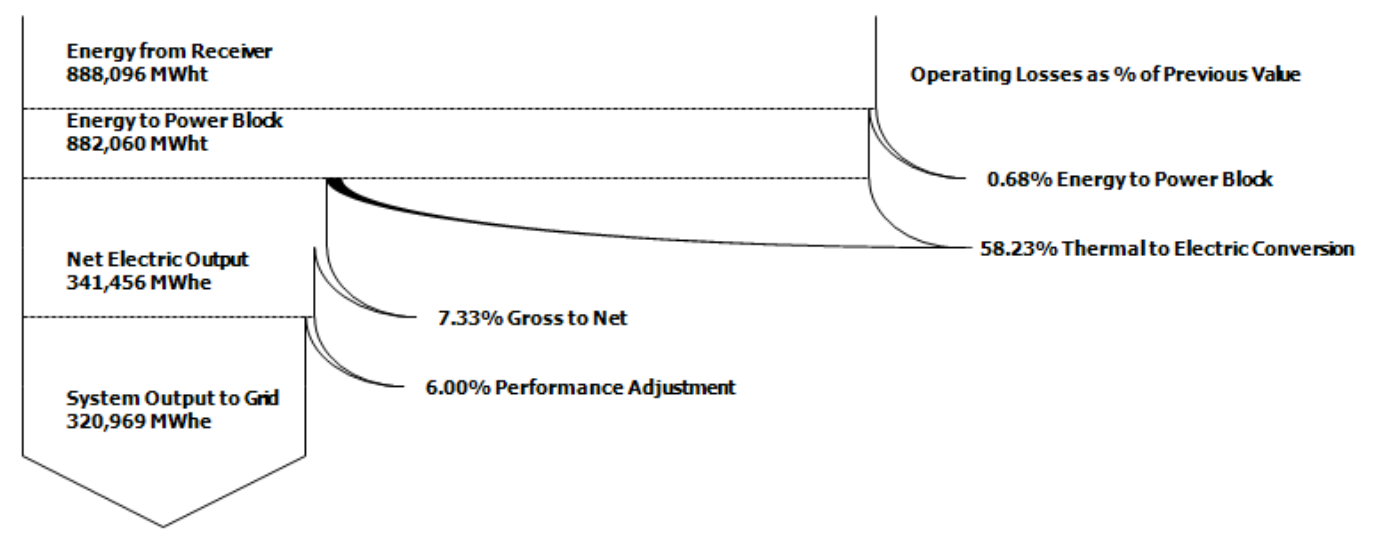

Fig.(14).Annual energy distrubution for case-2.

Table(5). The key financial indicators for Case-2

\begin{tabular}{ccccc}
\hline & NPV & $\begin{array}{c}\text { LCOE } \\
\text { Nominal, } \mathbf{c} / \mathbf{k W h e}\end{array}$ & $\begin{array}{c}\text { LCOE } \\
\text { Real, } \mathbf{c} / \mathbf{k W h e}\end{array}$ \\
\hline Financing Senario-1 (i=3\%) & $\begin{array}{c}173,168,656 \\
\text { (Revenue) } \\
\text { Financing Senario-2 }(\mathrm{i}=6 \%)\end{array}$ & 15.54 & 12.54 & 11.9 \\
(Revenue) & $181,633,888$ & 19.68 & 15.88 \\
\hline
\end{tabular}




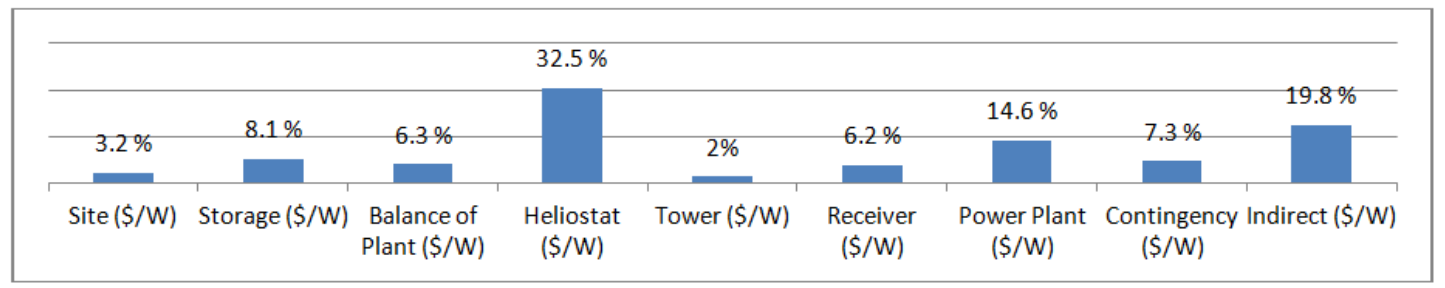

Fig.(15). Share of the plant componenets in the total capital cost(case-2).

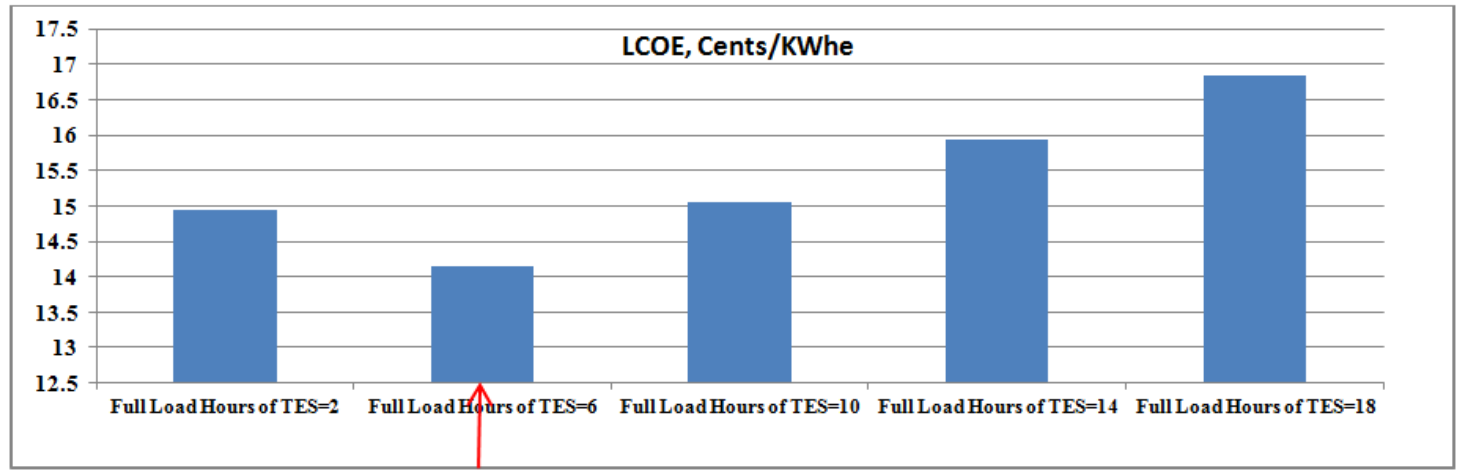

Fig.(16). Variation of LCOE versus SM at different storage capacities (case-2).

\section{Conclusion}

Solar energy from desert regions is promising to be a strong new market. MENA region has sufficient desert area which does not compete with agriculture or other uses, and high solar incidence during all seasons. CSP plants CSP power plant is a proposed type of renewable energy power plant. Where, it has been proved to be a promising large-scale power plant for future applications. This technology is suggested for use in MENA regions, where there is sufficient land, and solar radiation is good. Riyadh site has a high economical potential for CSP applications. In addition the electricity Transmission Lines network is supposed to be close, which makes the connection of is easy and low cost. Also, the water source is supposed to be available.

Two systems of CSP technologies are proposed and studied (rated power is $100 \mathrm{MW}$ for each case):a-PT solar field coupled with Steam turbo-generator (Case1). b-For desert areas solar tower//heliostats solar field coupled with gas turbo-generator (Case-2). It is concluded that:-

1-As estimated for case-1, the total solar field aperture area is $860,000 \mathrm{~m}^{2}$. Amount of $1,948,760$ MWht of annual solar energy can be received and converted to a net of 363,892 MWhe as electricity that can be supplied to the grid. So the total conversion efficiency is $18.67 \%$. The LCOE is $13.41,17.24$ Cent $/ \mathrm{kWhe}$ at $3 \%, 6 \%$ interest rates respectively. The best thermal energy storage is 6hrs which achieve the minimum LCOE. The payback period is 9.08, 12.03 years at $3 \%, 6 \%$ interest rates respectively.
2- As estimated for case-2, the total solar field (heliostat) area of is 1,012,933.6 $\mathrm{m}^{2}$. Amount of 2,295,611 MWht of annual thermal energy can be received and converted to a net of $341,456 \mathrm{MWhe}$ as net electric output. So the total conversion efficiency is $12.54 \%$. The LCOE is $15,88 \mathrm{Cent} / \mathrm{kWh}$ at $3 \%, 6 \%$ interest rates respectively. The best thermal energy storage is 6hrs which achieve the minimum LCOE. The payback period is $8.08,10.03$ years at $3 \%, 6 \%$ interest rates respectively.

3-using Both cases, the average annual energy output from a $100 \mathrm{MW}$ (with 6hrs TES) is at LCOE ranging from $12: 17$ cent/kWhe which is still high compared to that generated by fossil fuel in KSA ( 9 cent/kWhe). Taking into consideration the limited resources of fossil fuel and its prices, the CSP technology is highly promising to contribute in energy security.

4-For future applications in desert areas where water supply is limited, case-2 is preferred.

5 -For both cases, the results have been compared in terms of two parameters: a-the estimated conversion efficiency for case $1(18.67 \%)$ is higher than that of case-2(14.87\%). b-The LCOE is close to each other of both cases. 
6- Case- 1 uses superheated steam at about $400^{\circ} \mathrm{C}$ to drive steam turbine represent about $88 \%$ of the worldwide installed CSP capacity and about $97.5 \%$ of all capacity which is currently under construction. In the other hand, solar tower/heliostats plants uses air at up to $1000{ }^{\circ} \mathrm{C}$ and more (Case-2) are the only available option to provide solar heat for gas turbines and combined cycle systems. This option is the best choice for desert areas. Noting that case-2 is still uncertain and still leaves open questions with respect to cost, reliability and scalability for mass production at large scale.

\section{Nomenclature}

$\begin{array}{ll}\text { CAPEX } & \text { Capital Expenditure } \\ \text { DNI } & \text { Direct normal insolation, kwh } / \mathrm{m}^{2} \\ \text { PT } & \text { Parabolic trough } \\ \text { So To } & \text { Solar tower } \\ \text { LCOE } & \text { Levelized cost of energy, } \$ / \mathrm{kWhe} \\ \text { CSP } & \text { Concentrated solar power } \\ \text { MENA } & \text { Middle east and north Africa } \\ \text { MWht } & \text { Megawatt hour thermal power } \\ \text { MWhe } & \text { Megawatt hour electric power } \\ \text { TES } & \text { Thermal energy storage } \\ \text { i } & \text { Interest rate, } \% \text { year } \\ \text { IRR } & \text { Internal rate of return, } \% \\ \text { NPV } & \text { Net present value, } \$ \\ \text { OPEX } & \text { Operational Expenditure } \\ \text { HVAC } & \text { Heating, ventilating and air } \\ & \text { conditioning } \\ \text { PPA } & \text { power purchase agreement } \\ \text { SAM } & \text { System advisor model } \\ \text { Subscripts } & \\ \text { e } & \text { electric } \\ \text { t } & \text { thermal } \\ \text { Greek Symbols } \\ \eta & \text { Efficiency } \\ \end{array}$

\section{References}

[1] The Arabian desert solar energy consortium proposal,2011"feasibility study part-1 $1 \mathrm{GW} / \mathrm{h}$ power plant" Desert energy project

[2] MENA Regional Water Outlook, Part II Desalination Using Renewable Energy Task 2 - Energy Requirement,2011.

[3] Wilde,R, 2005 " Case Study of a Concentrating Solar Power Plant for the Cogeneration of Water and Electricity" Diploma thesis, DLR.

[4] http://www.eere.energy.gov/buildings/energyplus/cfm/ weather data.cfm.

[5]NREL Solar Data and Tools.

[6]International Renewable energy Agency (IRENA), 2012"CSP cost analysis"
[7]Daniel Horst, 2012" Performance Simulation For Parabolic Trough Concentrating Solar Power Plants And Export Scenario Analysis For North Africa"

MSc thesis, Faculty of Engineering, Cairo University Giza, Egypt.

[8]Technical Manual for the SAM Physical Trough Model, 2011.

[9]SAM program ver. 2012/ help menu.

[10]Michael J. Wagner, 2012 "Results and Comparison from the SAM Linear Fresnel Technology Performance Model" World Renewable Energy Forum Denver, Colorado May 13-17, 2012.

[11]C. Turchi, 2010" Parabolic Trough Reference Plant for Cost Modeling with the Solar Advisor Model (SAM)" Technical Report NREL/TP-550-47605 July 2010.

[12]Donald G. Newnan, "Engineering Economy Applying Theory to Practice" Oxford University, New York.

[13]William,G., Elin,M., and C.Patrick, 2009 ,Engineering economy handbook, Fourteenth edition, Pearson education Inc. New Jersey.

[14]Angela M., 2006"Simulation and Performance Evaluation of Parabolic Trough Solar Power Plants"MSc thesis, University of WISCONSINMADISON.

[15]Modeling and Analysis of CSP Systems, National Renewable Energy Laboratory, NREL/FS-550-48661 - August 2010.

[16]Bader,R., 2011" Optical and Thermal Analysis of an air-based solar trough concentrating system"PhD thesis, DISS. ETH NO. 19772.

[17]Dustin F. Howard, 2010" Modelling, Simulation, and analysis of grid connected Dish-Stirling Solar Power Plants"MSc theses, Georgia Institute of Technology.

[18]Modeling and Analysis of CSP Systems, National Renewable Energy Laboratory, NREL/FS-550-48661 - August 2010.

[19]Sargent \& Lundy LLC Consulting Group Chicago, Illinois,2003" Assessment of Parabolic Trough and Power Tower Solar Technology Cost and Performance Forecasts" NREL/SR-550-34440.

[20]International Renewable energy Agency (IRENA), 2012"CSP cost analysis"

[21] Turchi,C., Mehos,M., Ho,C.K., Kolb ,G.J.,2010 "Current and Future Costs for Parabolic Trough and Power Tower Systems in the US Market" Conference Paper, NREL/CP-5500-49303.

[22]CSP today, 2013 "CSP projects \& prospects guide USA 2013" WWW.csptoday.com/USA

[23]CSP today, 2008"An overview of CSP in Europe and MENA "MENASOL2013, WWW. CSPtoday.com/mena.

[24]C. Turchi,2010" Parabolic Trough Reference Plant for Cost Modeling with the Solar Advisor Model (SAM)" Technical Report NREL/TP-550-47605 July 2010. 